\title{
It's time to 'out' the selfish researchers
}

Sir - I recently had considerable difficulty in obtaining a clone from the authors of a paper published in Nature. The reason the authors gave for their initial refusal to supply the clone was because they did not wish to form new collaborations and that they had links to pharmaceutical companies. This prompts me to make two points.

First, it is one of the conditions of publication in Nature (and many other scientific journals) that "authors are required to make materials and methods freely available to academic researchers for their own use", including DNA sequences. This policy is stated clearly in the guide for authors submitting papers to Nature. What can be done if the authors fail to abide by these conditions after publication? An article cannot be withdrawn in retrospect, but it should be possible for a journal to refuse to publish further papers from such authors without firm reassurances that the conditions are adhered to in future. However, this would be difficult for a journal to police, and in itself raises ethical questions.

Perhaps it is for those researchers who come across such restrictive practices to 'out' these groups in the hope that others will take note and embarrass them by peergroup pressure. All researchers can understand the concern of overlapping research and the pressures of having competition in their own area of interest. But this tends to generate healthy debate and discussion. I suspect that most researchers would rather be working in a competitive area than a backwater with no competition.

Second, I am concerned that, because of collaborative work with an academic institute, a company can inhibit the ability of other academics to work in this area by restricting the distribution of material, and hence maintain a degree of control over the subject. All pharmaceutical companies are secretive about their research to try to gain an advantage over their competitors and to protect patentable advances. The pharmaceutical industry is a repository of knowledge that may never reach the public domain: for example, a previous correspondent has complained about the lack of published data on lexipafant hindering his ability to defend his thesis (Nature 395, 431; 1998).

But, although I am not against members of the pharmaceutical industry trying to protect their research data, I am against them hindering interest-driven research elsewhere. This is against the spirit in which many scientists conduct their work and this type of practice should not be allowed to creep into public institutions. Academic research should be for the benefit of all and we should pursue our goals with the intention of disseminating that knowledge freely.

\section{Noel C. Harris}

Division of Neuroscience,

The Medical School, University of Birmingham, Birmingham B15 2TT, UK

\section{PMs and policemen are} \section{getting younger}

Sir - Older people commonly complain that they do not enjoy the respect of younger generations. The complaint is the more bitter because they feel they would have been respected in old age had they been born a century earlier. In the absence of any data from the eighteenth and nineteenth centuries to test the validity of this complaint, I decided to analyse the age at which British prime ministers and US presidents first took office. I reasoned that, by and large, voters would elect a leader from an age group they respected.

The results (Fig. 1) reveal a striking contrast between the two countries. British prime ministers became progressively older through the eighteenth and nineteenth centuries. In the twentieth century this trend is reversed. In the United States, there is no significant pattern. There were several quite old presidents at the outset, as four Founding Fathers took turns in the job. In the twentieth century, there have been some notably old presidents (Ronald Reagan and George Bush) and some notably young ones (John F. Kennedy and Bill Clinton).

The British changes could have some connection with changes in the demographic profile of voters. Increases in life expectancy will make voters older on average while extensions in the franchise may have the reverse effect. The former is likely to be the stronger effect. However, I
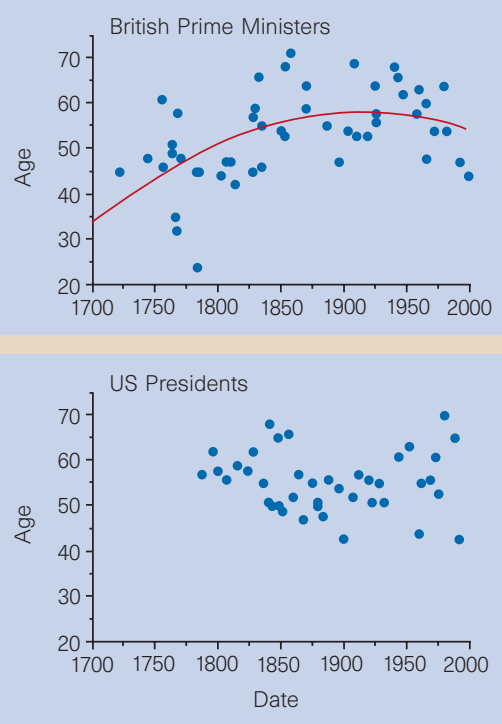

Figure 1 The age at which British prime ministers and US presidents first came to power plotted against the year in which they assumed office. The US data show no significant trend but the British pattern is highly significant $(P<\mathbf{0 . 0 0 1})$, and the line shows the fitted second order polynomial.

wish to offer an alternative perspective.

Biologists commonly argue that contests for mates and/or resources are often resolved by honest signals of quality ${ }^{1}$. Since such signals are costly to display, they cannot be displayed by low-quality cheats and therefore they reliably signal the high quality of the signaller. Could such arguments apply to the British data?
Two hundred years ago, the ability to survive beyond 50 indicated a genetic constitution able to cope with an environment where disease was widespread. Only in this century did life expectancy advance beyond 50 in developed countries ${ }^{2}$. Today, UK life expectancy is over 70 , and survival to that age has ceased to indicate anything much about genetic constitution.

In Victorian times, prime ministers were drawn from the élite of society and proved their ability to operate in that stable milieu. In today's more rapidly changing society, there is a case to be made that the ideal prime minister is one who has risen to prominence quickly because he or she shows the necessary flexibility to lead the nation in a time of transformation.

I suggest that British voters give the top job to somebody whose attributes are honest signals of ability in the society of the day. Prime ministers became older as life expectancy increased. But the pattern reversed this century when voters realized that an elderly member of the élite was no longer a likely possessor of useful physical or social qualities. At a less elevated level, this may sadly mean that today's older people are correct to grumble about lack of respect. What is less evident is why US voters are not following the British pattern.

\section{M. de L. Brooke}

Department of Zoology, University of Cambridge, Downing Street, Cambridge CB2 3EJ, UK

1. Johnstone, R. A. in Behavioural Ecology, 4th edn (eds Krebs, J. R. \& Davies, N. B.) 155-178 (Blackwell, Oxford, 1997).

2. Cohen, J. E. How Many People can the Earth Support? (W. W. Norton, New York, 1995). 